\title{
A Model for FeSiMg Alloy Production by Reduction Technique
}

\author{
Saeed Nabil Saeed Ghali
}

Steel Technology Department, Central Metallurgical Reseach \& Development Institute (CMRDI), P.O Box 87 Helwan, 11722, Egypt.

\section{ABSTRACT}

Ferrosilicon magnesium is basic foundry alloys used for the production of ductile cast iron. Magnesium content plays an important role in the produced alloy grades from dolomite ore. The focus of the present work is to simulate mathematical model to predict magnesium content in the ferrosilicon magnesium, which produced by silicothermic reduction of calcined dolomite. The basic assumptions of this model are: constant low viscosity of molten charge, the reaction is irreversible of second order and the reaction is isothermal. The reaction is based on the following equation:

$$
2 \mathrm{MgO}+2 \mathrm{Si} \rightarrow \mathrm{Mg}_{2} \mathrm{Si}+\mathrm{SiO}_{2}
$$

The results of previous work was found to be in a good coincidence with the predicted values by the model

$$
[M g]=\frac{\left(M g O_{o}\right)\left[S i_{o}\right]\left[e^{K t\left[\left(M g O_{o}\right)-\left[S i_{o}\right]\right]}-1\right]}{\left(M g O_{o}\right)\left[e^{K t\left[\left(M g O_{o}\right)-\left[S i_{o}\right]\right]}\right]-\left[S i_{o}\right]}
$$

where $[\mathrm{Mg}]$ is the concentration of magnesium metal in ferrosilicon magnesium alloy in mol/L. [Si $i_{o}$ and $\left(\mathrm{MgO}_{o}\right)$ are the initial concentration of silicon and magnesium oxide in charge in $\mathrm{mol} / \mathrm{L}$, while $t$ is time in second, $K$ is the reaction rate constant $\left(3.26588 \times 10^{-7} \mathrm{~L}\right.$ $\left.\mathrm{Sec}^{-1} \mathrm{~mol}^{-1}\right)$. The predicted values are greater than the experimental values; this may be attributed to the use of concentration instead of the activity. The predicted values of magnesium content in ferrosilicon magnesium alloy are in a good agreement with the experimental results obtained in previous work at low viscosity.

Keywords: activity, model, ferrosilicon, magnesium, reduction, viscosity

\section{INTRODUCTION}

Ferrosilicon magnesium is the one alloy of magnesium that is used to produce all types of ductile iron casting under all types of foundry conditions. Dolomite represents a source of both magnesium and calcium as it consists mainly of double carbonate of $\mathrm{Ca}$ and $\mathrm{Mg}$. Calcinated dolomite seems to be a suitable cheap raw material for the production of 
ferrosilicon magnesium alloy in EAF or in induction furnace [1-7]. The production of ferrosilicon magnesium from dolomite could be carried out either by metallothermic process using silicon and / or Al or by carbothermic process [8-13].

Magnesium content plays an important role in the produced alloy grades from dolomite ore. The silicothermic process of magnesium oxide is controlled by factors. The most important factors are physical properties of slag, the concentrations of reactants, reaction rate constant, reaction time and reaction temperature. At constant temperature, time and low viscosity the reaction rate mainly depends on the concentrations of reactants. In this paper, a mathematical model will be designed to predict magnesium content in ferrosilicon magnesium alloy which is produced by silicothermic reaction of calcinated dolomite at low viscosity of slag.

\section{MATHEMATICAL MODEL}

The focus of the present work is to create a mathematical model to predict magnesium content in ferrosilicon magnesium alloy, which is produced by silicothermic reduction of calcinated dolomite. The basic assumption of this model is the low and almost unchangeable viscosity of slag during the reaction. Ferrosilicon magnesium alloy is produced by reduction of calcinated dolomite ore with ferrosilicon containing silicon 75 mass content in $\%$. The reaction is based on the equation:

$$
2(\mathrm{MgO})+2[\mathrm{Si}] \stackrel{\mathrm{K}}{\longrightarrow}\left[\mathrm{Mg}_{2} \mathrm{Si}\right]+\left(\mathrm{SiO}_{2}\right)
$$

This system is controlled by chemical and kinetic roles. The limitations of this model are the following:

- The reaction takes place at low slag viscosity and nearly unchanged

- The above reaction is isothermal and irreversible

- The reaction is second order

- Concentration of reducing agent (in molar) is greater than the magnesium oxide ( [Si] $>(\mathrm{MgO}))$

- There is a mass balance in the above reaction

The rate of change of magnesium content in ferrosilicon magnesium alloy is directly proportional to the concentration of magnesium oxide and silicon metal. There is a mass balance in this system.

$$
(\mathrm{MgO})+[\mathrm{Si}] \stackrel{\mathrm{K}}{\longrightarrow} \frac{1}{2}\left[\mathrm{Mg}_{2} \mathrm{Si}\right]+\frac{1}{2}\left(\mathrm{SiO}_{2}\right)
$$

$\left[\mathrm{Mg}_{2} \mathrm{Si}\right]$ go to molten metal and $\left(\mathrm{SiO}_{2}\right)$ go to slag. Every one mole from $\left[\mathrm{Mg}_{2} \mathrm{Si}\right]$ has two moles from $\mathrm{Mg}$, i.e. the rate of change of $\mathrm{Mg}$ with time depends on the initial concentrations of the reactants. 
The reaction in equation (2) means that one mole from magnesium oxide reduced by one mole of silicon metal to give one mole of magnesium. This can be writing as:

$$
(\mathrm{MgO})+[\mathrm{Si}] \stackrel{K}{\longrightarrow}[\mathrm{Mg}]
$$

The above reaction can be rewrite as:

$$
\begin{aligned}
& A+B \stackrel{K}{\longrightarrow} X \\
& \left(A^{o}-X\right)+\left(B^{o}-X\right) \stackrel{K}{\longrightarrow} X
\end{aligned}
$$

Where at zero time:

$(\mathrm{MgO})=$ initial concentration of magnesium oxide $=\left(\mathrm{MgO}_{\mathrm{o}}\right)=\mathrm{A}^{\mathrm{o}}$

$[\mathrm{Si}]=$ initial concentration of silicon metal $=\left[\mathrm{Si}_{\mathrm{o}}\right]=\mathrm{B}^{\mathrm{o}}$

$[\mathrm{Mg}]=$ initial concentration of magnesium metal $=\mathrm{X}=$ Zero

At any time:

$$
\begin{aligned}
& (\mathrm{MgO})=\mathrm{A}=\mathrm{A}^{\mathrm{o}}-\mathrm{X} \\
& {[\mathrm{Si}]=\mathrm{B}=\mathrm{B}^{\mathrm{o}}-\mathrm{X}} \\
& {[\mathrm{Mg}]=\mathrm{X}}
\end{aligned}
$$

From equation (3), the rate of change in magnesium content is directly proportional with the concentrations of reactants.

$$
\frac{d[M g]}{d t}=K(M g O)[S i]
$$

From equations $9,10,11 \& 12$, we obtain

$$
\frac{d x}{d t}=K\left(A^{o}-X\right)\left(B^{o}-X\right)
$$

Rearrange and integration of two sides of equation (13)

$$
\begin{aligned}
& \int \frac{d x}{\left(A^{o}-X\right)\left(B^{o}-X\right)}=K \int d t \\
& \int \frac{d x}{\left(A^{o}-X\right)\left(B^{o}-X\right)}=K t+\text { cons } \tan t
\end{aligned}
$$

The left side of equation (15)

$$
\begin{aligned}
& \frac{1}{\left(A^{o}-X\right)\left(B^{o}-X\right)}=\frac{C_{1}}{\left(A^{o}-X\right)}+\frac{C_{2}}{\left(B^{o}-X\right)} \\
& \frac{1}{\left(A^{o}-X\right)\left(B^{o}-X\right)}=\frac{C_{1}\left(B^{o}-X\right)+C_{2}\left(A^{o}-X\right)}{\left(A^{o}-X\right)\left(B^{o}-X\right)}
\end{aligned}
$$


From the parameters of $X$

$0=-C_{1}-C_{2}$

From the parameters of $\mathrm{X}^{0}$

$1=C_{1} B^{0}+C_{2} A^{o}$

From equations (18) and (19)

$C_{1}=\frac{1}{B^{o}-A^{o}}$
$C_{2}=\frac{1}{B^{o}-A^{o}}$

From equations (15), (16), (20) and (21), the left side of equation (15)

$\int \frac{d x}{\left(A^{o}-X\right)\left(B^{o}-X\right)}=\frac{1}{B^{o}-A^{o}} \int \frac{d x}{\left(A^{o}-X\right)}+\frac{1}{A^{o}-B^{o}} \int \frac{d x}{\left(B^{o}-X\right)}$

Take

$\mathrm{y}=\mathrm{A}^{0}-\mathrm{x}$

$\mathrm{z}=\mathrm{B}^{0}-\mathrm{X}$

and hence $\quad d y=-d x$

From equations (22-26)

$\int \frac{d x}{\left(A^{o}-X\right)\left(B^{o}-X\right)}=\frac{1}{B^{o}-A^{o}}\left[-\int \frac{d y}{y}+\int \frac{d z}{z}\right]$

$\int \frac{d x}{\left(A^{o}-X\right)\left(B^{o}-X\right)}=\frac{1}{A^{o}-B^{o}}\left[\int \frac{d y}{y}-\int \frac{d z}{z}\right]$

$\int \frac{d x}{\left(A^{o}-X\right)\left(B^{o}-X\right)}=\frac{1}{A^{o}-B^{o}}[\ln y-\ln z]$

$\int \frac{d x}{\left(A^{o}-X\right)\left(B^{o}-X\right)}=\frac{1}{A^{o}-B^{o}}\left[\ln \frac{y}{z}\right]$

From equations (23), (25) and (30)

$\int \frac{d x}{\left(A^{o}-X\right)\left(B^{o}-X\right)}=\frac{1}{A^{o}-B^{o}}\left[\ln \frac{\left(A^{o}-X\right)}{\left(B^{o}-X\right)}\right]$

From equations (15) and (31)

$\frac{1}{A^{o}-B^{o}}\left[\ln \frac{\left(A^{o}-X\right)}{\left(B^{o}-X\right)}\right]=K t+$ const .

From boundary conditions, at zero time, from equation (8), $\mathrm{X}=0$

$\frac{1}{A^{o}-B^{o}}\left[\ln \frac{A^{o}}{B^{o}}\right]=$ const .

From equations (32) and (33)

$$
\begin{aligned}
& \frac{1}{A^{o}-B^{o}}\left[\ln \frac{\left(A^{o}-X\right)}{\left(B^{o}-X\right)}\right]=K t+\frac{1}{A^{o}-B^{o}}\left[\ln \frac{A^{o}}{B^{o}}\right] \\
& \frac{1}{A^{o}-B^{o}}\left[\ln \frac{\left(A^{o}-X\right)}{\left(B^{o}-X\right)}\right]-\frac{1}{A^{o}-B^{o}}\left[\ln \frac{A^{o}}{B^{o}}\right]=K t
\end{aligned}
$$




$$
\begin{aligned}
& \frac{1}{A^{o}-B^{o}}\left[\ln \frac{B^{o}\left(A^{o}-X\right)}{A^{o}\left(B^{o}-X\right)}\right]=K t \\
& {\left[\ln \frac{B^{o}\left(A^{o}-X\right)}{A^{o}\left(B^{o}-X\right)}\right]=K t\left(A^{o}-B^{o}\right)} \\
& \frac{B^{o}\left(A^{o}-X\right)}{A^{o}\left(B^{o}-X\right)}=e^{K t\left(A^{o}-B^{o}\right)} \\
& \left(A^{o}-X\right)=\frac{A^{o}}{B^{o}}\left(B^{o}-X\right) e^{K t\left(A^{o}-B^{o}\right)} \\
& \left(A^{o}-X\right)=\left(A^{o}-\frac{A^{o}}{B^{o}} X\right) e^{K t\left(A^{o}-B^{o}\right)} \\
& \left(\frac{A^{o}}{B^{o}} X^{*} e^{K t\left(A^{o}-B^{o}\right)}-X\right)=A^{o} e^{K t\left(A^{o}-B^{o}\right)}-A^{o} \\
& X\left[\frac{A^{o}}{B^{o}} e^{K t\left(A^{o}-B^{o}\right)}-1\right]=A^{o}\left[e^{K t\left(A^{o}-B^{o}\right)}-1\right] \\
& \left.X=\frac{A^{o}\left[e^{K t\left(A^{o}-B^{o}\right)}-1\right]}{A^{o}} e^{K t\left(A^{o}-B^{o}\right)}-1\right] \\
& B^{o} \\
& X=\frac{A^{o} B^{o}\left[e^{K t\left(A^{o}-B^{o}\right)}-1\right]}{\left[A^{o} e^{K t\left(A^{o}-B^{o}\right)}-B^{o}\right]} \\
& {[M g]=\frac{\left(M g O_{o}\right)\left[S i_{o}\right]\left[e^{K t\left[\left(M g O_{o}\right)-\left[S i_{o}\right]\right]}-1\right]}{\left(M g O_{o}\right)\left[e^{K t\left[\left(M g O_{o}\right)-\left[S i_{o}\right)\right]}\right]-\left[S i_{o}\right]}}
\end{aligned}
$$

At initial time, $\mathrm{t}=0$

$$
[\mathrm{Mg}]=\frac{\left(\mathrm{MgO}_{o}\right)\left[S i_{o}\right]\left[e^{0}-1\right]}{\left(\mathrm{MgO}_{o}\right)\left[e^{0}\right]-\left[S i_{o}\right]}=1
$$

This means that the model verifies the boundary conditions In case of $\mathrm{K}$ is very large, and $[\mathrm{Si}]>(\mathrm{MgO})$,

From equation (45)

$$
\begin{aligned}
& {[\mathrm{Mg}]=\frac{\left(\mathrm{MgO} \mathrm{O}_{o}\right)\left[S i_{o}\right]\left[e^{\infty * t\left[\left(M g O_{o}\right)-\left[S i_{o}\right]\right]}-1\right]}{\left(M g O_{o}\right)\left[e^{\infty * * t\left[\left(M g O_{o}\right)-\left[S i_{o}\right]\right]}\right]-\left[S i_{o}\right]}} \\
& {[M g]=\frac{\left(M g O_{o}\right)\left[S i_{o}\right]\left[e^{-\infty}-1\right]}{\left(M g O_{o}\right)\left[e^{-\infty}\right]-\left[S i_{o}\right]}} \\
& {[M g]=\frac{-\left(M g O_{o}\right)\left[S i_{o}\right]}{-\left[S i_{o}\right]}=\left(M g O_{o}\right)}
\end{aligned}
$$

This means that all magnesium oxide will be reduced by silicon In case of at infinity time and $[\mathrm{Si}]>(\mathrm{MgO})$

$$
[M g]=\frac{\left(M g O_{o}\right)\left[S i_{o}\right]\left[e^{\left.K^{*} \infty^{*}\left(M g Q_{0}\right)-\left[S_{i}\right]\right]}-1\right]}{\left(M g O_{o}\right)\left[e^{\left.\left.K^{*} \infty^{*}\left(M g Q_{o}\right)-S S_{o}\right]\right]}\right]-\left[S i_{o}\right]}=\left(M g O_{o}\right)
$$


It is clear that the model verify both the boundary conditions and logical limits.

From equation (1), it can be calculate the rate of reaction using Gibbs free energies of constituents

$$
\begin{aligned}
& 2(\mathrm{MgO})+2[\mathrm{Si}] \stackrel{K}{\longrightarrow}\left[\mathrm{Mg}_{2} \mathrm{Si}\right]+\left(\mathrm{SiO}_{2}\right) \\
& \Delta G=\Delta G_{P}-\Delta G_{R} \\
& \Delta G_{P}=\Delta G_{\mathrm{Mg}_{2} S i}+\Delta G_{\mathrm{SiO}_{2}} \\
& \Delta G_{R}=2 \Delta G_{\mathrm{MgO}}+2 \Delta G_{S i} \\
& \Delta G_{\mathrm{MgS}_{3}}=6.4 x 10^{3} \mathrm{Call} \mathrm{mol}=2679 \mathrm{JJ} / \mathrm{mol}[14] \\
& \Delta G=\Delta H-T \Delta S \quad[15] \\
& \quad \Delta G_{\mathrm{SiO}_{2}}=-217570-(1873)(-48.79)= \\
& \quad-12618633 \mathrm{Cal} / \mathrm{mol}=-52834216 \mathrm{~J} / \mathrm{mol} \\
& 2 \Delta G_{\mathrm{MgO}}=2[-253754-(1873)(-41.9) \\
& =-1752753 \mathrm{Cal} / \mathrm{mol}=-73384837 \mathrm{~J} / \mathrm{mol} .
\end{aligned}
$$

\begin{tabular}{|c|c|c|c|c|c|c|c|c|c|c|c|}
\hline \multirow[t]{2}{*}{ No } & \multicolumn{8}{|l|}{ Input } & \multicolumn{2}{|c|}{ Output } & \multirow{2}{*}{$\begin{array}{l}\text { Mg mass } \\
\text { content in } \\
\% \text { Predicted }\end{array}$} \\
\hline & Dolomite & $\mathbf{F e S i}$ & Fluorspar & Limestone & Al & Quartzite & Bauxite & $\mathrm{CaSO}_{4}$ & $\begin{array}{l}\text { Metal } \\
\text { mass }\end{array}$ & $\begin{array}{l}\text { Mg mass } \\
\text { content in \% }\end{array}$ & \\
\hline 1 & 1250 & 750 & 100 & 50 & & & & 25 & 725 & 2.25 & 4.38 \\
\hline 2 & 1250 & 750 & 100 & 70 & & & & 25 & 590 & 2.86 & 5.30 \\
\hline 3 & 1250 & 750 & 100 & 100 & & & & 25 & 550 & 4.1 & 5.54 \\
\hline 4 & 1250 & 750 & 100 & 130 & & & & 25 & 430 & 2.0 & 6.90 \\
\hline 5 & 1250 & 750 & 100 & 150 & & & & 25 & 441.5 & 1.3 & 6.61 \\
\hline 6 & 1250 & 600 & 160 & & 50 & 50 & & 25 & 480 & 1.7 & 5.48 \\
\hline 7 & 1250 & 600 & 160 & & 50 & 75 & & 25 & 558 & 1.8 & 4.60 \\
\hline 8 & 1250 & 600 & 160 & & 50 & 100 & & 25 & 622 & 3.2 & 4.04 \\
\hline 9 & 1250 & 600 & 160 & & 50 & 150 & & 25 & 813 & 1.6 & 2.96 \\
\hline 10 & 1250 & 600 & 40 & & 50 & & & 25 & 750 & 1.76 & 4.11 \\
\hline 11 & 1250 & 600 & 80 & & 50 & & & 25 & 489 & 3.5 & 6.06 \\
\hline 12 & 1250 & 600 & 120 & & 50 & & & 25 & 550 & 3.5 & 5.19 \\
\hline 13 & 1250 & 600 & 160 & & 50 & & & 25 & 575 & 4.24 & 4.78 \\
\hline 14 & 1250 & 600 & 200 & & 50 & & & 25 & 595 & 3.25 & 4.45 \\
\hline 15 & 1250 & 600 & 400 & & 50 & & & 25 & 550 & 3.25 & 4.05 \\
\hline 16 & 1250 & 950 & 160 & & & & 50 & 25 & 983 & 2.45 & 3.19 \\
\hline 17 & 1250 & 950 & 160 & & & & 100 & 25 & 828 & 2.84 & 3.67 \\
\hline 18 & 1250 & 950 & 160 & & & & 150 & 25 & 731 & 3.05 & 3.99 \\
\hline 19 & 1250 & 950 & 160 & & & & 200 & 25 & 805 & 2.52 & 3.50 \\
\hline 20 & 1250 & 950 & 160 & & & & 250 & 25 & 750 & 2.63 & 3.62 \\
\hline
\end{tabular}

From equations (51) \& (54-57)

$$
\begin{aligned}
& \Delta G=[26796.8+(-528342.16)]-[-733848.37+0]=232303.01 \mathrm{~J} / \mathrm{mol} . \\
& K=10^{\frac{-\Delta G}{2.3 R T}}=10^{-6.486}=3.26588 \times 10^{-7} \mathrm{~L}^{*} \mathrm{~mol}^{-1} * \mathrm{Sec}^{-1}
\end{aligned}
$$

The model is applied for the experimental results of Hoda et al [16]. Tables (1-2) show the constituents and chemical compositions of charges respectively.

Table 1: The charge of experimental 
Table 2: Chemical composition of charge

\begin{tabular}{|c|c|c|c|c|c|c|c|c|}
\hline \multirow[t]{2}{*}{ Constituents } & \multicolumn{8}{|c|}{ Chemical composition, mass content in $\%$} \\
\hline & Calcinated dolomite & Fluorspar & Rare earth metals & Limestone & Quartzite & Bauxite & $\mathrm{FeSi}$ & $\mathrm{Al}$ \\
\hline $\mathrm{SiO}_{2}$ & 1.4 & 12.6 & & 3.88 & 95 & 6.43 & & \\
\hline $\mathrm{Fe}_{2} \mathrm{O}_{3}$ & 1.45 & 0.35 & & 0.5 & 0.2 & & & \\
\hline $\mathrm{CaO}$ & 62.4 & & 1 & 51.78 & & & & \\
\hline $\mathrm{MgO}$ & 33.6 & & 1 & 0.6 & 0.3 & & & \\
\hline L.O.I. at $1000^{\circ} \mathrm{C}$ & 0.43 & & & 41.3 & & & & \\
\hline $\mathrm{Al}_{2} \mathrm{O}_{3}$ & 1 & 2.4 & & 0.8 & 2.5 & 85 & & \\
\hline $\mathrm{Na}_{2} \mathrm{O}$ & & & 1 & 1.64 & & & & \\
\hline $\mathrm{K}_{2} \mathrm{O}$ & & & & 0.35 & & & & \\
\hline $\mathrm{CaF}_{2}$ & & 82 & & & & & & \\
\hline $\mathrm{CaCO}_{3}$ & & 2.2 & & & & & & \\
\hline $\mathrm{P}_{2} \mathrm{O}_{3}$ & & & 0.01 & & & & & \\
\hline $\mathrm{CeO}_{2} / \mathrm{ReO}$ & & & 45 & & & & & \\
\hline $\mathrm{Fe}$ & & & 0.005 & 0.34 & 0.14 & & 23.3 & \\
\hline $\mathrm{Pb}$ & & & 0.001 & & & & & \\
\hline $\mathrm{P}_{2} \mathrm{O}_{5}$ & & 0.001 & & & & & & \\
\hline $\mathrm{SO}_{3}$ & & & 0.03 & & & & & \\
\hline $\mathrm{FeO}$ & & & & & & 1.8 & & \\
\hline $\mathrm{C}$ & & & & & & & 0.09 & \\
\hline $\mathrm{S}$ & & & & & & & \begin{tabular}{|l|}
0.003 \\
\end{tabular} & \\
\hline $\mathrm{P}$ & & & & & & & 0.031 & \\
\hline $\mathrm{Al}$ & & & & & & & 1.41 & 99. \\
\hline $\mathrm{Ca}$ & & & & & & & 0.31 & \\
\hline $\mathrm{Si}$ & & & & & & & 74.8 & \\
\hline
\end{tabular}

Figs (1-4) show the actual and predicted magnesium content at different contents of bauxite, limestone, fluorspar and quartzite respectively, the time of reaction is two hours. Fig. 1 shows that the effect of bauxite (alumina content) as given in Tables (1-2) on the magnesium content and the difference between predicted and actual magnesium content. It is clear that the difference between the magnesium mass content in $\%_{\text {pred. }}$ and magnesium mass content in $\%_{\text {actual }}$ increase as the alumina increase. This behaviour can be attributed to the negative effect of $\mathrm{Al}_{2} \mathrm{O}_{3}$ on the activity of magnesium oxide due to the formation of calcium aluminates [8; 17-18]. Fig.2 shows the difference between the predicted magnesium content and the actual magnesium cont at different limestone. It is noted that - as clear from Fig. 2 - the difference between the predicted and the actual magnesium content decreases as the limestone increases (from heats 1 to 3 ) then the difference, by further limestone increase (heats $4 \& 5$ ), the difference sharply increase. This can be explained by two significant opposite effect. The first one is the positive effect of increasing $\mathrm{CaO}$ content - due to increase limestone- in $\mathrm{SiO}_{2}$ rich slag leading to the formation of $2 \mathrm{CaO} . \mathrm{SiO}_{2}, 3 \mathrm{CaO} . \mathrm{SiO}_{2}$ and $\mathrm{CaO} . \mathrm{SiO}_{2}$ [19-25]. these compounds are formed first and are very stable leading to free $\mathrm{MgO}$ for reduction, this mean that the activity of magnesium oxide increase by increasing limestone to some extent. The second factor, is the negative effect of increasing the content of these high molten compounds $\mathrm{CaO} . \mathrm{SiO}_{2}, 2 \mathrm{CaO} . \mathrm{SiO}_{2}$ and $3 \mathrm{CaO} \mathrm{SiO}_{2}$ with melting temperatures of $1564{ }^{\circ} \mathrm{C}, 2130{ }^{\circ} \mathrm{C}$ and $2070{ }^{\circ} \mathrm{C}$, respectively, resulting in higher viscous slag and hence the activity of magnesium oxide decrease. Furthermore, the presence of $\mathrm{CO}_{2}$ gas, resulting from the decomposition of limestone leads to more oxidation of magnesium. Fig. 3 shows the variation between the 
predicted and actual magnesium content with difference fluorspar content. The actual magnesium content near to the predicted magnesium content by increasing fluorspar content in the charge through heat numbers 10 up to 13, but by further addition of fluorspar, the actual values of magnesium content began to far from predicted values. These results can be illustrated as follow, the low deviation of actual magnesium content from predicted one; this is as a result of increasing activity of magnesium oxide [26]. On the other hand, addition of more fluorides to silicate slag results in silicon tetra fluoride $\left(\mathrm{SiF}_{4}\right)$ vapour [27], and hence concentration of silicon decreases.

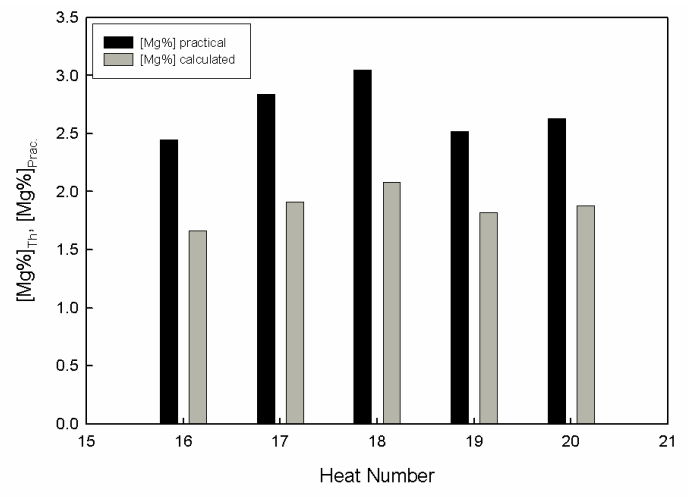

Fig.1: The difference between calculated and actual Mg content in presence of Bauxite

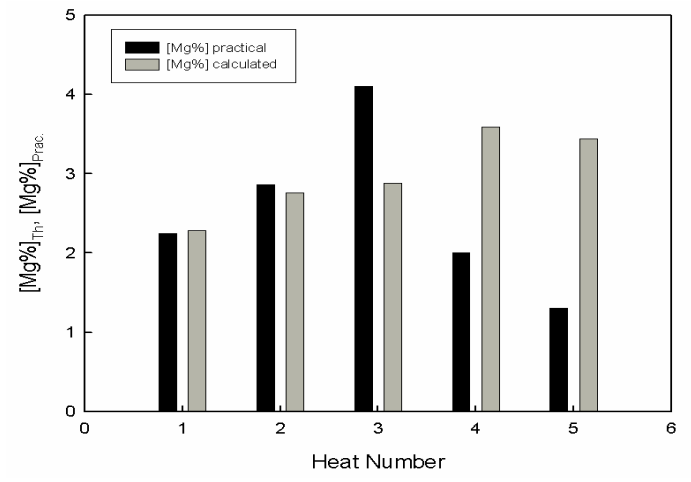

Fig. 2: The difference between calculated and actual Mg content in presence of limestone

It is clear that, the difference between the actual and predicted magnesium content through heats 6 to 9 (in which quartzite content increase) decreases up to heat number 8 then followed by increasing as given in Fig.4. This behaviour can be investigated as follow. There are two opposite factors. The first one, there is a constant distribution of silicon between metal and slag at a given temperature. Therefore, as the slag is saturated with $\mathrm{SiO}_{2}$, the silicon content in the alloy increases, also leading to high recovery of magnesium content which cause low deviation in magnesium between actual and predicted contents. The second factor, by further addition of quartzite, the activity of magnesium oxide decreases [28-29], this is due to the formation of $2 \mathrm{MgO} . \mathrm{SiO}_{2}$ [30]. On the other side, the excess $\mathrm{SiO}_{2}$ tends to form a less stable compound such as $\mathrm{Ca}_{3} \mathrm{Mg}\left(\mathrm{SiO}_{2}\right)$ [31-32], which is dissociated to $\mathrm{Ca}_{2} \mathrm{SiO}_{4}$ with a high melting point leading to high viscous slag.

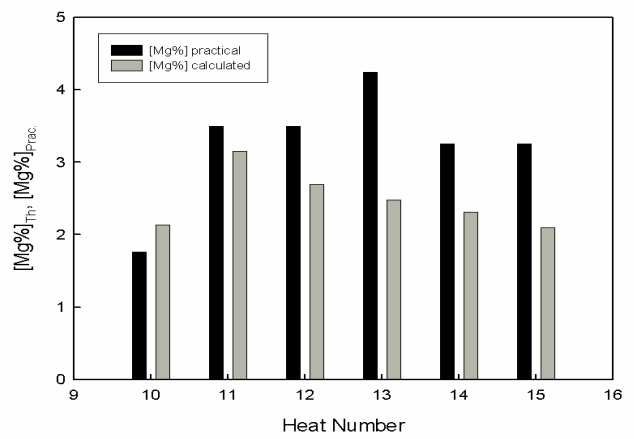

Fig. 3: The difference between calculated and actual $\mathrm{Mg}$ content in presence of fluorspar

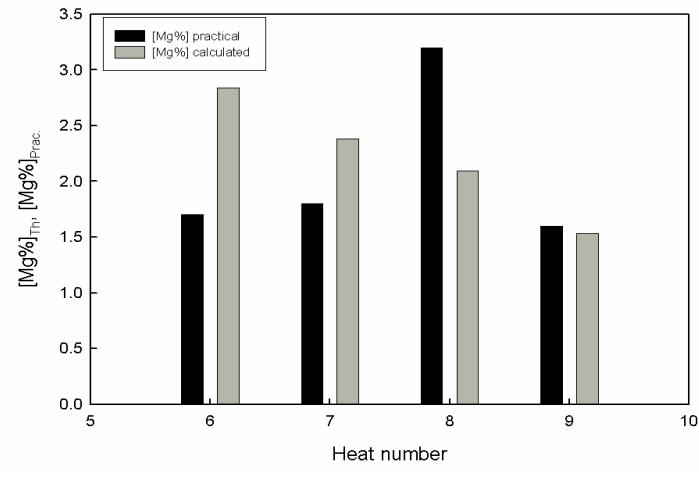

Fig. 4: The difference between calculated and actual $\mathrm{Mg}$ content in presence of quartzite. 


\section{CONCLUSIONS}

The predicted magnesium contents are greater than the experimental values. The most important reason is attributed to the use of concentrations instead of activities.

- Based on the assumptions, low viscosity, and the reduction of magnesium oxide by silicon metal, the reaction is controlled by rate of reaction and concentration of reactants $(\mathrm{MgO})$ and $[\mathrm{Si}]$.

- The equation have been derived is function in initial concentration of reactants, time, reaction rate constant as shown, $[\mathrm{Mg}]=\frac{\left(\mathrm{MgO} \mathrm{O}_{o}\right)\left[S i_{o}\right]\left[e^{K t\left[\left(M g O_{o}\right)-\left[S i_{o}\right]\right]}-1\right]}{\left(\mathrm{MgO}_{o}\right)\left[e^{K t\left[\left(M g O_{o}\right)-\left[S i_{o}\right]\right]}\right]-\left[S i_{o}\right]}$

- The reaction rate constant of the reaction : $2(\mathrm{MgO})+2[\mathrm{Si}] \stackrel{\mathrm{K}}{\longrightarrow}\left[\mathrm{Mg}_{2} \mathrm{Si}\right]+\left(\mathrm{SiO}_{2}\right)$ is $\mathrm{K}=3.26588 \times 10^{-7} \mathrm{~L}^{*} \mathrm{~mol}^{-1} * \mathrm{Sec}^{-1}$

- Volatilization of magnesium metal during the reduction of magnesium oxide process has a great negative significant effect on the gab between the predicted and actual values of magnesium content.

- Finally the difference between the actual and predicted mainly depends on effect of additions on the activities of magnesium oxide and reducing agent, and viscosity of the reaction medium.

\section{REFERENCES}

1. 461964 (U.S.S.R.), 8(1975), M. A. Kekelidze et al., Auth. Cert., Bynll. Izobr.,

2. M. A. Ryss et al.: Stal, April, (1973), p. 303.

3. D. I. Saginadze et al.: Stal, 2 (1977), p.140.

4. D. I. Saginadze et al.: Steel in the USSR, 16 (1986), p. 533

5. F. N. Tavadze et al.: Nauka Proizvodstva, C51, (1983), p. 243.

6. 727704 (U.S.S.R.), 14(1980), F. N. Tavadze et al., Auth. Cert., Bynll. Izobr.

7. V. Varbanov et al.: Works of the Iron and Steel Inst., VIII (1977).

8. D. J. G. Ives: Principles of the extraction of metals, London, (1969).

9. H. J. T. Ellingham: I. Soc. Chem. Ind., Lond., 1944 \& C.W. Dannatt and H.J.T. Ellingham: Disc Faraday Soc., 4 (1948), p. 126

10. N. P. Lyakiskev et al.: Alyuminotermiya "Aluminothermy", Moscow, (1978), p. 424

11. M. A. Merritt and E. V. Marcossi: Electric Furnace Conf. Proc., New York, 29 (1972), p. 184.

12. V. Ryachikov, V. G.. Mizin., and A. S. Dubrovin: Steel In U.S.S.R., 12 (1982), p. 264.

13. P. Sokolov and N. L. Ponomarov: Introduction to Metallothermic, Moscow, (1990), p. 134.

14. W. Klemm and H. Wwstlinning: Z.anorg. Chem., 245, (1941), p. 365.

15. R.G. Ward, M.A., Ph. D: An introduction to the physical chemistry of iron \& steel making, Edward Arnold (Publishers) LTD, (1962), p. 212/213.

16. H. El-Faramawy et al.: Ferrosilicon Magnesium Production, Scandinavian Journal of Metallurgy, 32 (2003) p. 37/46.

17. M. Alper, et al: J. Am. Ceram. Soc., 45 (1962) No. 6, p. 263/8 
18. R. A. Howald \& N. B. Roy: CALPHAD 15(1991) No. 2, p. 159/72

19. B. Ellingstaeter \& T. Rosenquist: Journal of Metals, 6 (1956), p. 111.

20. L M. Pidgeon: Trans Met Soc AIME, 226 (1963) p. 821

21. L. M. Pidgeon \& J. K. King: Trans Faraday Soc, 40 (1948) p. 197.

22. V. Ryabchikov \& A. S. Mikulinskii: Chemical Abstract, 35 (1962) p. 62.

23. J. M. Taguri \& L M. Pidgeon: Can J Chem, 39 (1961) p. 540

24. K. Tomasek, I. Imsis \& O. Sesveiec: Light Metals, Proc. Conf., Montreal, Quebec, 2529 August (1996) p. 213

25. J. R. Wynnyckj, L. M. Pidgeon: Met Trans 2 (1971) p. 979

26. C. Chen \& W. Zhao: Acta Met. Sinica, 19 (1983) No. 1, A1/A8

27. K. C. Mills \& B. J. Keene: Int Metal Review, 1 (1981) p. 21/69

28. J. F. Elliott, M. Gleiser \& V. Ramakrishna: Thermochemistry for Steelmaking. Vol. II, Reading. Palo Alto/London (1963).

29. H. R. Rein, J. Chipman: Trans. Metallurg. Soc. AIME, 233 (1965), p. 415/425

30. S. Kambayashi, E. Katao: J. Chem. Thermodyn. 15 (1983) No. 8, p. $701 / 707$

31. W. T. Hughes, C. E. Ransky \& E. F. Emle: Advan Extr Met Proc Symp, London (1968) 429

32. R. B.Winkler: Vacuum metallurgy, Elsevier, London, (1971)193 